\title{
HACE1 Gene
}

National Cancer Institute

\section{Source}

National Cancer Institute. HACE1 Gene. NCI Thesaurus. Code C119637.

This gene is involved in both protein ubiquitination and Golgi membrane dynamics. 